\title{
Tomasz Ferenc*
}

\section{STAN WOJENNY \\ W OPOWIEŚCIACH BIOGRAFICZNYCH \\ POLSKICH ARTYSTÓW EMIGRANTÓW}

\begin{abstract}
Abstrakt. Wprowadzenie stanu wojennego w Polsce w 1981 r. miało poważne konsekwencje polityczne, społeczne i gospodarcze. Jest to okres, w którym znacząco wzrósł potencjał emigracyjny wśród Polaków. Znalazło to swoje odzwierciedlenie także wśród środowisk twórczych. Artykuł ukazuje losy artystów, którzy zdecydowali się na wyjazd z kraju lub też na trwałe pozostanie poza Polską. Korzystając z opowieści biograficznych twórców mieszkających w Paryżu, Berlinie, Londynie i Nowym Jorku, wyodrębniono te fragmenty narracji, które dotyczyły właśnie tego okresu. Ukazano rozmaite okoliczności wyjazdów w kontekście czynników osobistych, środowiskowych oraz historycznych. Mimo że losy poszczególnych artystów mają za każdym razem indywidualny rys, możliwe jest zrekonstruowanie społecznych mechanizmów wpływających na podejmowane przez nich decyzje oraz ukazanie wspólnych doświadczeń emigrantów. Istotnym elementem tekstu jest też zwrócenie uwagi na system represji stosowanych przez ówczesne władze, np. na tzw. politykę paszportową. Tekst obok prezentacji losów polskich twórców podejmuje problem emigracji w kategorii kulturowej straty, którą ponosi nie tylko jednostka opuszczająca swój kraj, lecz także pozostawiane przez nią społeczeństwo.
\end{abstract}

Słowa kluczowe: emigracja, artyści, stan wojenny, represje, polityka paszportowa, asymilacja.

\section{Wstęp}

Emigrację z Polski należy rozpatrywać jako istotne zjawisko społeczne, kulturowe, polityczne oraz ekonomiczne, którego natężenie stało się widoczne w perspektywie globalnej. Począwszy od XIX w., poprzez wiek XX aż do współczesności Polacy odznaczają się niezwykłą aktywnością migracyjną.

W ruchach migracyjnych szczególnie zaznacza się obecność Polaków. Plasują się oni na czwartym miejscu po Chińczykach, Niemcach i Włochach pod względem wielkości jako społeczność narodowościowa zamieszkująca poza granicami kraju. Szacuje się, że na świecie zamieszkuje ok. 25 mln ludzi mających polski rodowód (C h o d u b s k i 2003: 55).

* Dr hab., prof. UŁ, Katedra Socjologii Sztuki, Instytut Socjologii, Wydział Ekonomiczno-Socjologiczny, Uniwersytet Łódzki, ul. Rewolucji 1905 r. 41/43, 90-214 Łódź; e-mail: tomasz.ferenc@wp.pl. 
Należy zatem zadać pytanie, dlaczego właśnie Polacy tak często i licznie opuszczają swoją ojczyznę? Powody tych wyjazdów są różne w poszczególnych okresach historycznych. Należy jednak podkreślić czynnik ekonomiczny jako dominujący. W historii naszego kraju równie istotna w kontekście emigracji była także sytuacja geopolityczna. Deportacje, wymuszone przesiedlenia, represje, działania wojenne powodowały nieustanny migracyjny ruch, w którym licznie uczestniczyli artyści. Nie ulega wątpliwości, że skala tego zjawiska zasadniczo wpłynęła na kształt polskiej kultury. Dla wielu twórców było to jedno z przełomowych doświadczeń biograficznych, istotne nie tylko dla wyjeżdżających, lecz także dla bliskich pozostających w kraju. Badając polską kulturę artystyczną, należy zatem uwzględnić znaczącą rolę twórców emigrantów.

Zjawisko emigracji artystów jest ważne, lecz do tej pory słabo rozpoznane w perspektywie socjologicznej. Z tego powodu w roku 2006 rozpocząłem trwający kilka lat proces gromadzenia materiałów na temat polskich twórców mieszkających w Berlinie, Paryżu, Londynie oraz w Nowym Jorku¹. W miastach tych odszukać można najliczniejsze skupiska artystów, co wynika z ich metropolitalnego charakteru i wciąż dominującej pozycji centrów kulturowych. Aby zbadać ten społeczny fenomen, przyjąłem, że najodpowiedniejszym metodologiczno-teoretycznym zakotwiczeniem badania będzie biograficznie zorientowana socjologia sztuki. Wykorzystanie metody biograficznej okazało się właściwym sposobem na gromadzenie danych mogących służyć próbie poznania społecznych światów artystów, zaś teorie wypracowane przez socjologię sztuki pozwoliły na interpretację mechanizmów funkcjonowania różnych systemów artystycznych. W badaniu tym nie koncentrowano się jedynie na twórcach, którzy odnieśli sukces poza granicami Polski. Poszukiwano też osób, które nie osiągnęły znaczącej pozycji w artystycznym świecie (biorąc pod uwagę kryteria instytucjonalnej teorii sztuki) ${ }^{2}$. Nie zmienia to faktu, że osoby takie wciąż pozostają artystami, podejmującymi działania twórcze w ramach dostępnych im możliwości czasowych, finansowych, środowiskowych itd. Uzasadnione staje się zatem pytanie o to, kim są artyści. Na trudności w precyzyjnym zdefiniowaniu tego pojęcia zwrócił uwagę Andrzej Osęka.

${ }^{1}$ W czasie trwania badania zostało zebranych 61 wywiadów narracyjnych. W Paryżu przeprowadzono 16 wywiadów, w Londynie - 15, w Nowym Jorku - 21, w Berlinie - 9. Pierwsze materiały zostały zgromadzone podczas dwóch wizyt w Paryżu, latem 2006 i 2007 r. Kolejne wywiady zrealizowano w roku 2007 w Londynie i Berlinie oraz na przełomie lat 2007 i 2008 w Nowym Jorku. Uczestników badania rekrutowano metodą kuli śnieżnej, inicjując ją rekonesansem przeprowadzanym w każdym z miast. Jeden z wywiadów został przeprowadzony w Krakowie w czasie pobytu artysty w Polsce. Wszystkie wywiady zostały zarejestrowane oraz poddane pełnej transkrypcji, a wyniki badań opublikowano w książce: F e r e n c (2012).

2 Problem pozycji zajmowanej przez artystę w świecie sztuki oraz niejednoznaczności definiowania sukcesu przybliżony został w tekście: F e r e n c (2014). 
Trudno określić, kogo się ma na myśli, mówiąc: artysta. Czy chodzi o malarza, poetę, kompozytora? Czy jest artystą aktor? Śpiewak estradowy? Ten, co projektuje etykietki? Czy aby nazwać kogoś artystą, trzeba zgodnej opinii ogółu, czy może wystarczy jego wewnętrzne przekonanie? Czy interesuje nas tu jedynie twórca wielki, o którym prędzej czy później powiedzą, że jest geniuszem, wyrasta ponad swą epokę, czy również autor obrazów, wierszy - niezdolnych do tego, by wyjść poza krąg rzeczy już widzianych, już powiedzianych? (O s ę k a 1975: 12).

Marian Golka świadomy tych kłopotów, odwołując się do rozważań autorów tak wpływowych, jak Pierre Bourdieu, Florian Znaniecki czy cytowany już Andrzej Osęka, proponuje następujące rozwiązanie:

artystą jest człowiek zajmujący się działalnością twórczą o indywidualnym charakterze, znamionującą biegłość, a przy tym wskazującą zaangażowanie talentu, wyobraźni i innych cech osobowości, która to działalność pełni swoistą funkcję społeczną, zaakceptowaną przez zbiorowość w wyniku zapotrzebowania na określone wartości, które artysta może oferować ( $\mathrm{G}$ o 1 k a 2008: 77).

Wszyscy artyści biorący udział w badaniu wpisują się swoimi działaniami oraz postawami w powyższą definicję, choć zajmują oni rozmaite pozycje statusowe w polu sztuki. Cechują ich predyspozycje osobowościowe oraz wysoki poziom warsztatowych umiejętności i biegłość w swoich dziedzinach artystycznych. Reprezentują oni rozmaite dziedziny sztuki: malarstwo, grafikę, plakat, rzeźbę, fotografię, sztuki filmowe i sztukę wideo, performance, literaturę, muzykę oraz taniec.

Punktem wyjścia każdej narracji stawał się opis przyczyn i okoliczności wyjazdu z Polski. Analizując zebrany materiał, starano się w poszczególnych opowieściach uchwycić milieu, czynniki historyczne oraz czynniki osobiste kształtujące przebieg biografii. Zazwyczaj te trzy elementy pojawiały się z różnym natężeniem w większości zebranych narracji. Pozwoliło to na wyodrębnienie kilku głównych powodów wyjazdów oraz szeregu powiązanych z nimi okoliczności towarzyszących. Wyróżniono zatem grupę dominujących czynników push i pull . Do pierwszego typu determinantów należy zaliczyć szereg czynników, takich jak: represje polityczne (w tym wprowadzenie stanu wojennego), ograniczenie

3 Teoria push and pull, sformułowana w latach 60. XX w. przez Everetta S. Lee (1966), stała się jedną $\mathrm{z}$ bardziej popularnych socjologicznych koncepcji wyjaśniających zjawisko migracji. Pierwszy z czynników (push) ma działanie wypychające z własnego kraju, zaś drugi (pull) przyciągające do innego kraju lub obszaru osiedlenia. Bardzo często oba te czynniki działają równocześnie i jeden z nich może wzmacniać drugi. W kompleksie przyczyn może pojawić się jeden decydujący faktor oraz wiele innych towarzyszących i wzmacniających decyzję o emigracji. Do czynników push Lee zalicza m.in.: brak pracy, głód, słabą opiekę medyczną, katastrofy naturalne, zanieczyszczenie środowiska, złe warunki mieszkaniowe, prześladowania polityczne, brak wolości słowa i wyznania, dyskryminację, ograniczone szanse na znalezienie życiowego partnera i założenie rodziny, brak poczucia bezpieczeństwa. Wśród czynników pull znajdują się natomiast: szansa uzyskania zatrudnienia, lepsze warunki życia, wolność polityczna i religijna, lepsza opieka medyczna, bezpieczeństwo, uprzemysłowienie, edukacja, powiązania rodzinne (migracja łańcuchowa). 
kontaktów ze światem zewnętrznym, brak możliwości swobodnej artystycznej ekspresji, wreszcie ogólną ekonomiczną zapaść kraju. Dominującymi czynnikami przyciągającymi - pull - stawała się sytuacja osobista (związek z osobą pochodzącą spoza Polski), psychiczne predyspozycje do wyjazdu (np. postawa kosmopolityczna), głównie jednak szeroko rozumiana chęć poprawy własnego losu. Bardzo często podkreślano w narracjach pragnienie kontynuowania artystycznego lub naukowego rozwoju, wskazywano także na poszukiwanie możliwości zmiany i nowych perspektyw życiowo-artystycznych.

Decyzje o wyjeździe z kraju z reguły wynikały ze splotu wielu okoliczności. Nie zawsze były efektem konkretnie sprecyzowanego biograficznego planu jednostki, mającego prowadzić do emigracji, lecz krystalizowały się w toku kolejnych życiowych doświadczeń. Bardzo często czynniki polityczne i ekonomiczne splatały się w jeden silny impuls, skłaniający do opuszczenia Polski przede wszystkim ludzi młodych, niewidzących dla siebie szans na normalne życie w komunistycznym kraju.

\section{Skutki wprowadzenia stanu wojennego w opowieściach artystów}

Badanie biografii artystów przypomina pod wieloma względami wielokrotne studium przypadków z niezwykle zróżnicowaną treścią oraz formą poszczególnych opowieści. Mimo to można wskazać w nich wspólne elementy, podobne doświadczenia biograficzne oraz zbliżone czynniki historyczne i środowiskowe wpływające na przebieg życia jednostki. Jednym z takich powracających motywów narracyjnych były opowieści dotyczące stanu wojennego i jego wpływu na życie uczestników badania. Stan wojenny został wprowadzony 13 grudnia 1981 r. uchwałą Rady Państwa podjętą na polecenie Wojskowej Rady Ocalenia Narodowego. 31 grudnia 1982 r. został zawieszony, a 22 lipca 1983 r. zniesiony. Wprowadzenie stanu wojennego dla bardzo wielu ludzi żyjących w Polsce było wydarzeniem dotkliwym, nawet traumatycznym. Trafnie tę sytuację charakteryzuje Paweł K a c z m a r c zyk (2005): „Czasowe zamknięcie granic ze względu na wprowadzenie stanu wojennego jedynie zwiększyło potencjał migracyjny, bowiem wzrosło poczucie bezsilności i nieufności względem systemu" (t a m że: 122). Wiele osób nigdy nie myślących o opuszczeniu kraju zaczęło redefiniować swoje życiowe plany. W poszczególnych przypadkach ujawniono rozmaite eksplikacje powodów emigracji. Jedną z wielu przyczyn była niemożliwość swobodnego realizowania w Polsce artystycznych projektów oraz kontynuowania dalszego samorozwoju:

W 1980 roku, kiedy wszystko wydawało się możliwe i wiele rzeczy można było zrealizować, i ani wcześniej ani potem się tego tak nie czuło, no to widziałem moją aktywność tylko w Polsce, natomiast stan wojenny wszystko przekreślił. I nie brałem tego pod uwagę, że będę tutaj na stałe, no ale jeśli człowiek mieszka gdzieś, w jakimś mieście, to tam zapuszcza korzenie (wywiad 3, Paryż, performer). 
Sytuacja polityczna i gospodarcza kraju doprowadziła do powstania potężnego czynnika push. Jednak brak perspektyw na poprawę warunków życia, na rozwój kariery artystycznej, dotkliwe ograniczenie kontaktów ze światem - wywołały silny impuls emigracyjny jeszcze przed wprowadzeniem stanu wojennego. Dobrze sytuację tę charakteryzuje fragment opowieści artysty mieszkającego w Nowym Jorku.

Są osoby, które dokładnie planują tego typu wyprawy, w moim przypadku nie było to przemyślane jako wyjazd, jako emigracja zaplanowana, raczej spontaniczna. 1981 rok, skończyłem szkołę, zrobiłem dyplom z malarstwa w Krakowie, pracownia, małżeństwo, mieszkanie. Małżonka pracuje, ja jako artysta nie mam dużo możliwości w tym okresie. Młode małżeństwo, małe mieszkanie, trzeba kupić stereo, nową lodówkę. Jeździło się za granicę, żeby zarobić. Jeździłem do Szwecji, Wiednia. Nowy Jork miał podobny charakter, w Polsce mieliśmy wszystko: mieszkanie, dużą pracownię z suszarni na dziesiątym piętrze w nowych blokach. Gdy chcieliśmy urządzić mieszkanie, to pojawił się pomysł - skocz do Nowego Jorku, zarób. Moi koledzy tak funkcjonowali, wyjechał na rok do Stanów, kupował nowy samochód i szpanował. To było naturalną rzeczą, naturalnym działaniem, szczególnie dla artystów, bo albo byłeś asystentem na uczelni, albo nauczycielem w liceum, albo robiłeś chałtury. Nie dało się żyć ze sztuki, po malarstwie. Wyjazd był więc konsekwencją ekonomiczną, latem 1981 roku. Oczywiście cały ten burdel, jaki był w Polsce, cała ta sytuacja solidarnościowa, brak papieru, mleka, wszystkiego, powodowała jeszcze bardziej, zmusiła cię wręcz, żebyś wyjechał. Pamiętaj, że ten background, tło naszego życia, sytuacja, w jakiej znajdowali się młodzi ludzie, młode małżeństwo, nie mówiąc o społeczeństwie, była fatalna - albo uciekasz, albo się rozpijasz, albo strzelasz sobie w głowę, no bo jakie perspektywy były? Perspektywa, że wstajesz rano i przez trzy godziny będziesz stał w kolejce, żeby kupić mleko? Takie były nasze warunki. Albo wyjeżdżasz, zarabiasz, i jesteś facetem, albo, kurwa mać, płaczesz. Nie było ani się w co ubrać, ani coś zjeść, ani zrobienia kariery. Miałem 27 lat, byłem ambitnym facetem, chciałem coś z sobą zrobić. No i pojawiła się decyzja wyjazdu do Stanów, zarobienia czegoś i powrotu (wywiad 2, Nowy Jork, malarz, grafik, ilustrator).

W powyższym fragmencie opowieści narrator, uzasadniając przyczyny swojego wyjazdu, odwołuje się zarówno do milieu, omawiając rozmaite uwarunkowania rodzinne i środowiskowe, jak i do czynników historycznych, zwracając uwagę na trudne warunki życia w Polsce na początku lat 80. Narrator, podobne jak wielu innych, nie widząc dla siebie szans na rozwój kariery artystycznej ani atrakcyjnych możliwości zarobkowych, zdecydował się na wyjazd. W końcowej części wypowiedzi ujawniony zostaje też istotny wpływ czynnika emocjonalnego. Emigracja w takim ujęciu staje się ratunkiem, ale także aktem odwagi, decyzją o podjęciu działań, poszukiwaniem rozwiązania w okolicznościach, w których jednostka nie widzi dla siebie i swojej rodziny szans na normalne funkcjonowanie. Powody emigrowania z Polski do USA w pierwszej połowie lat 80. nie różniły się od tych wymienianych przez twórców, którzy osiedlili się w państwach europejskich. Konfiguracja czynników push i pull dla tego okresu historii polskiej emigracji jest zasadniczo stała. 
Wprowadzenie stanu wojennego nie zawsze oznaczało natychmiastowe podjęcie starań o wyjazd z Polski. Kształtowało jednak plany biograficzne na przyszłość i trwale zmieniało stosunek do własnego kraju. Tak stało się w przypadku twórcy, który osiedlił się w Berlinie. Opisując okoliczności wpływające na podjęcie decyzji o wyjeździe, narrator ukazuje swoje akademickie milieu:

Postanowiłem wyjechać z Polski 13 grudnia 1981 - prosta i banalna sytuacja. Oglądałem film braci Taviani Święty Michał miał koguta i on został przerwany o północy, poszedłem spać. Rano Jaruzelski, decyzja: wyjeżdżam z kraju, ten kraj mnie nie interesuje, poczułem się skrzywdzony jak dziecko, które postanowiło zmienić coś w swoim otoczeniu i dostało po łapach. Pracowałem wtedy na UJ, gdzie wcześniej studiowałem, potem pracowałem przez chwilę w AGH, skąd wróciłem na uniwersytet, bo byłem tam niemile widziany, bo nie zapisałem się do partii. Bardzo śmieszne, a właściwie zadziwiające, ale w sumie bardzo normalna sytuacja, to znaczy bardziej partyjny szef instytutu filozofii AGH przyjmował według kryterium jakościowego, a uniwersytet według kryterium partyjnego, bo takie były naciski. Jak się zogniskuje spojrzenie w mniejszej skali, to jest zadziwiające w swoim rodzaju. W 1983 roku pozwolono mi wrócić na uniwersytet (wywiad 4, Berlin, tłumacz, literat, kurator).

Czas, który upłynął między podjęciem decyzji o emigracji a ostatecznym zrealizowaniem tego zamiaru narrator poświęcił m.in. na zakończenie swojej pracy badawczej. W wielu analizowanych opowieściach wspominano o tym specyficznym okresie biograficznym. Przyczyny powodujące owe ,zawieszenie” są bardzo różne. Obok spraw zawodowych wymieniano jako kluczowe: kwestie rodzinne, potrzebę przygotowania wyjazdu, a także czynniki polityczne, np. często stosowaną przez administrację PRL odmowę wydania paszportu. W pierwotnym zamierzeniu artysty, podobnie jak w planach wielu Polaków, Berlin miał stać się jedynie przystankiem w drodze do Stanów Zjednoczonych:

W 1986 przyjechałem do Berlina, chciałem jechać do Ameryki, jak najdalej. To trwało długo, sześć lat ze względów technicznych, chciałem dokończyć doktorat, obronić, urodziło się moje drugie dziecko, syn [...] (wywiad 4, Berlin, tłumacz, literat, kurator).

Stan wojenny stał się zatem impulsem wywołującym gotowość do podjęcia emigracji, trwale modyfikującym plany życiowe. Wiele osób nie mogąc wyjechać w czasie jego trwania z powodów administracyjnych i politycznych (np. odmowa wydania paszportu), opuściło Polskę po zniesieniu stanu wojennego.

Małgorzata Warchoł-Schlottman przeprowadziła w odstępie kilku lat dwa badania polskich imigrantów mieszkających w Niemczech. Pierwsze z nich dotyczyło emigrantów solidarnościowych, drugie - reprezentantów emigracji, która nastąpiła po roku 1989. W obu przypadkach osoby biorące udział w badaniu należały do młodej inteligencji. Wyniki badań ukazały zmianę powodów i celów wyjazdów emigracyjnych. 
Wśród motywów emigracji z lat 80 . dominowały przyczyny polityczne i ekonomiczne, słowem brak jakichkolwiek perspektyw dla indywidualnego i zawodowego rozwoju [...]. Emigranci po roku 1989 jako najważniejszy powód wyjazdu podawali kontynuację wykształcenia, zebranie jak największych zawodowych doświadczeń i umiejętności [...], drugim w kolejności powodem opuszczenia kraju była ciekawość świata (Warchoł-S chlott man 2002: 369).

Autorka opisuje także zmianę schematów wyjazdowych. Przed rokiem 1989 emigracja często miała znamiona ucieczki, polegającej na niewracaniu z wycieczki turystycznej do jednego z zachodnich państw. Kwestia tego, jakie było to państwo, pozostawała sprawą drugorzędną, najważniejsze stawało się opuszczenie PRL. Dla bardzo wielu emigrantów nie miało to większego znaczenia również dlatego, że ostatecznym projektowanym celem emigracji były Stany Zjednoczone. Wielu Polaków właśnie z Berlina Zachodniego rozpoczynało swoją wędrówkę do Ameryki, ale też wielu spośród planujących docelowe osiedlenie się w USA pozostawało na terenie RFN. Obrazuje to poniższy cytat, w którym ukazane zostały zarówno czynniki osobiste, jak i historyczne uwarunkowania, w jakich znalazł się narrator.

Nie było moim celem, aby zostać w Berlinie, tylko udać się za ocean, jak najdalej od Polski, nie było moim programem wyjście jedną nogą, ponieważ to był pewnego rodzaju akt zerwania z nienawiścią, może to nie jest dobre słowo, ale rozczarowanej miłości, porzucony przez moją największą miłość i nie chciałem mieć z nią nic wspólnego, chciałem się od niej oddalić. Ale potykam się na pierwszym napotkanym przydrożnym kamieniu i zostaję w Berlinie Zachodnim. Ten Berlin Zachodni od samego początku mnie fascynuje, ten mur nie tylko jako ta sytuacja bycia otoczonym, bycia otorbionym w sytuacji uprzywilejowanej. Dla mnie naturalną sytuacją wydawało się bycie otorbionym w sytuacji wrzodu, gorszości. Byliśmy w obrębie żelaznej kurtyny, miałem kilka lat problem wyjechania z Polski, miałem zakaz wykonywania zawodu, zakaz uczenia, jakieś przesłuchania, jakieś kretyńskie ograniczenia, to wszystko wydawało mi się przynależne mojej sytuacji bycia rzuconym, że ja jestem wprawdzie otoczonym, ale w tym negatywnym sensie. A tu czuję się w sytuacji kogoś uprzywilejowanego, kogoś kto jest wolny (wywiad 4, Berlin, thumacz, literat, kurator).

Emigranci z lat 80. pozostający w Niemczech z reguły nie znali języka niemieckiego, co stanowiło pierwszą przeszkodę w rozpoczęciu normalnego życia. Osoby opuszczające kraj po roku 1989 z reguły posiadały przygotowany plan wyjazdu i dobrą znajomość języka niemieckiego. Ich sytuacja pod wieloma względami była zdecydowanie korzystniejsza od sytuacji emigrantów sprzed 1989 roku. Wyjazdy przestały być nieodwracalnym, dramatycznym punktem zwrotnym w biografii i - co najważniejsze - zyskały legalny charakter. Kolejna różnica między tymi dwoma kohortami dotyczy tego, co autorka nazywa „bagażem cywilizacyjnym”. Przyjazd z komunistycznej Polski do Niemiec Zachodnich oznaczał konieczność przeżycia szokującej konfrontacji z bogactwem, dobrobytem 
i różnorodnością w nieznanej do tej pory skali ${ }^{4}$. O tego rodzaju wrażeniach wspominali także artyści biorący udział w badaniu, np. artystka, która dotarła do Berlina $\mathrm{w} 1982 \mathrm{r}$ :

Pociąg przyjechał o ósmej rano, czekał na mnie ten kolekcjoner, który specjalnie wziął sobie wolne tego dnia, pracował w szpitalu. I jak wysiadłam, to wszystko było takie niesamowite, te kwiaciarnie, te świeże kwiaty na ulicach. Taki przyjemny świat dla oka, taki bezpieczny świat, takie normalne życie. Taki niesamowity kontrast po tym stanie wojennym (wywiad 3, Berlin, performerka).

Przyjazd z komunistycznego kraju na „zachód” z reguły wzbudzał silne emocje, graniczące wręcz z oszołomieniem. Pierwszy okres upływał zazwyczaj w euforycznym uniesieniu (,miodowy miesiąc” emigranta). Jest to faza zauroczenia, długo oczekiwany moment wyrwania się z biedy i braku wolności, faza krótkotrwałej beztroski przed rozpoczęciem trudu organizowania życia od początku:

W pewnym momencie mam pieniądze, żeby zaspokajać swoje potrzeby, nie muszę uganiać się za jedzeniem dla dzieci, za mlekiem w proszku, co jeszcze mi się to zdarzyło w 1984 roku. [...] W pewnym sensie jest to rausz w sensie materialnym i rausz wolnością, że można przeczytać każdą książkę, zobaczyć każdy film, można pojechać w każde miejsce, że nic się nie wydarzy, co temu przeszkodzi (wywiad 4, Berlin, tłumacz, literat, kurator).

Kiedy mija faza zauroczenia, następują kolejne, trudniejsze etapy wymagające skonfrontowania się z nowym środowiskiem, kulturą i językiem. Zasada realizmu bierze górę nad zasadą przyjemności. W tym czasie emigrant coraz intensywniej odczuwa kulturową obcość nowego środowiska. Jednostka musi podjąć wysiłek zorganizowania życia w nowej rzeczywistości, ponownie uzyskać status aktywnego uczestnika życia społecznego.

Potem zachodzi oczywiście taka sytuacja, że trzeba się na nowo zorientować, na nowo zacząć być podmiotem w tej rzeczywistości. I to jest, moim zdaniem, najbardziej interesujący przełom, który dotyczy emigranta (wywiad 4, Berlin, thumacz, literat, kurator).

W odmiennej sytuacji znaleźli się twórcy, którzy w momencie ogłoszenia stanu wojennego przebywali poza Polską . Tego rodzaju traumatyczne przeżycie stało się udziałem m.in. Janusza Głowackiego. W grudniu 1981 r. pisarz wyjechał

${ }^{4}$ Dziś możemy opisać to spotkanie w kategoriach zderzenia doświadczeń wyniesionych z kraju nieustannego ekonomicznego niedostatku - z rzeczywistością kraju dobrobytu, w którym na dobre funkcjonowało już społeczeństwo o charakterze konsumpcyjnym. W istocie ówczesna emigracja na Zachód oznaczała konieczność przejścia transformacji o charakterze cywilizacyjnym.

${ }^{5} \mathrm{~W}$ momencie wprowadzenia w Polsce stanu wojennego poza granicami kraju przebywało około 500 tys. osób, spośród których wiele zdecydowało się pozostać na emigracji. W grupie tej znalazła się także liczna reprezentacja artystów. 
do Londynu po to, aby uczestniczyć w próbach i w premierze swojej sztuki Kopciuch, wystawianej w Royal Court Theatre.

Ale trzynastego grudnia, właśnie w dniu, w którym moja ówczesna narzeczona Ewa miała wsiąść o ósmej do samolotu, odwiedzić Londyn, kupić sobie coś z ubrania i wziąć udział w uroczystościach, o siódmej rano obudził mnie telefon. Dzwoniła zaprzyjaźniona Nina Smolar z informacją, że generał Jaruzelski rozpoczął dobrze znaną polskim czytelnikom akcję (Gło w a c ki 2004: 7).

Dla bardzo wielu osób ogłoszenie stanu wojennego w Polsce doprowadziło do podjęcia ostatecznej decyzji o pozostaniu na emigracji. Tak stało się z liczną grupą polskich twórców wyjeżdżających co pewien czas do USA w celach zarobkowych.

Zarabiałem zupełnie nieźle w Polsce w porównaniu do moich kolegów po architekturze. Ja się nie przemęczałem. Tak że ja byłem zepsuty, nie wyjeżdżałem tutaj z głodu, wręcz przeciwnie. [...] Potem jak nastał stan wojenny, to Polakom przedłużali (wizy - przyp. T. F.). Dostałem nawet azyl polityczny przez to, że zrobiłem sobie zdjęcie na wystawie moich plakatów ze Zbigniewem Brzezińskim. To była persona. To znaczyło, że mogłem mieć problemy, jak wrócę do Polski. I to był główny powód, że dostałem paszport amerykański (wywiad 1, Nowy Jork, malarz, plakacista).

W kolejnym przypadku artysta także wyjechał do Nowego Jorku w celach zarobkowych i ponownie wprowadzenie stanu wojennego doprowadziło do zmiany planów biograficznych.

Kończy się lato, zaczyna jesień, czas leci, kiedy w Polsce zostaje wprowadzony marshall war, 13 grudnia 1981 roku zamykają się granice, dostaję wezwanie z ZOMO na służbę, ja się pytam rodziny, co mam robić? Nie wracaj. Rozumiesz, o co chodzi? Nie wracaj. Zostawaj, rób, co możesz robić, tylko nie wracaj. To samo mi mówi żona, nie wracaj. W tym momencie decyduję się na azyl polityczny, w 1982 roku, i dostaję ten azyl, i jestem legalnie (wywiad 2, Nowy Jork, malarz, grafik, ilustrator).

$\mathrm{W}$ trzecim przypadku, podobnie jak w poprzednim, wzmocnienie decyzji o pozostaniu na emigracji nastąpiło wskutek kontaktu z bliską osobą z Polski. Poniższy fragment sygnalizuje też dramatyczny problem rozłąki, która w momencie podjęcia decyzji o pozostaniu za granicą stawała się czasowo nieokreślona. W wielu przypadkach, jak w tej przytoczonej poniżej, trwająca nawet kilka lat.

Przyjechałem na trzy miesiące, zilustrować książkę, tu w Ameryce. No i stan wojenny nastał, to była główna przyczyna, dla której zostałem. Chciałem nawet wrócić [...]. Miałem narzeczoną, w której się kochałem, to było oczywiste, żebym wrócił. Ale okazało się, że nie ma biletu. Reagan wstrzymał loty i trzeba było przez Kanadę, nie miałem wtedy pieniędzy i to się przetoczyło. A jeszcze dostałem list od tej narzeczonej, żebym nie wracał, a ją ściągnął, bo miała kłopoty zdrowotne. Trwało to trzy lata, ale to już osobna historia. Ale to główna przyczyna. Nie wystąpiłem o azyl, ale jako znany artysta wystąpiłem o prawa, bo mnie upokarzało, żeby 
prosić o azyl, bo przy całej tej sytuacji politycznej, biedzie komunistycznej, nie czułem się represjonowany. [...] Zostałem przez Jaruzelskiego oddelegowany do tego miejsca i u mnie to się bardzo dobrze rozwijało. Odkryłem nowy kształt, założyłem własną firmę, to powodowało, że życie wzięło sprawy w swoje ręce. Przyjechałem na wakacje i do tej pory moje wakacje trwają. Na pytania ludzi, czy wyjeżdżam na wakacje, odpowiadam, nie wyjeżdżam, bo jestem. Jeżdżę nawet często do Polski, moja żona nawet woli w Polsce, tak że kto wie, czy w którymś momencie z wakacji nie wrócę (wywiad 4, Nowy Jork, grafik, ilustrator, wynalazca).

Wprowadzenie stanu wojennego wpłynęło zatem na losy wielu polskich artystów, często stając się decydującym czynnikiem determinującym pozostanie poza Polską. W wielu przypadkach były to osoby nieplanujące długotrwałej emigracji. Jak sądzę, również w tym kontekście możemy rozpatrywać stan wojenny jako ewidentną stratę dla polskiej kultury.

Nigdy nie chciałem emigrować, byłem parę razy w Anglii, tutaj [w Nowym Jorku - przyp. T. F.] w roku 1981, zanim tu przyjechałem. Nie miałem najmniejszych pomysłów na emigrację, tylko żeby mieszkać w Polsce. Interesował mnie Zachód z punktu takiego obserwatora. Jak tu przyjechałem 1 listopada 1981, film, który robiłem o Annie Walentynowicz, będąc jeszcze w Szkole Filmowej, został zaproszony przez MOMA, miałem ten film reprezentować, dostałem wizę amerykańską. Przyjechałem tutaj, ale film nigdy nie został z Polski wysłany, został uznany za antykomunistyczną propagandę, potem w „Żołnierzu Wolności” był artykuł na ten temat, już jak został wprowadzony stan wojenny, więc przyjechałem tutaj sześć tygodni przed stanem wojennym. [...] Nie było specjalnie po co wracać, nie było samolotów. Potem zobaczyłem informację o tym swoim filmie w „Żołnierzu Wolności”, którą ktoś mi przysłał. Zacząłem myśleć, czy powrót ma sens, bo to co się dzieje, wszyscy unieruchomieni, moi koledzy nie pracują, kompletna dziura w życiorysie, nie ma żadnych twórczych możliwości (wywiad 16, Nowy Jork, reżyser filmów dokumentalnych).

Informacje docierające do narratora $\mathrm{z}$ kraju oraz zatrzymanie jego filmu przez cenzurę spowodowały zmianę planów biograficznych. Artysta przed wyjazdem nie rozważał trwałego pozostania poza Polską. Jego decyzja była zatem przede wszystkim konsekwencją działania czynników historycznych.

\section{Doświadczenie represji, manipulacji oraz agitacji w opowieściach artystów}

Opowieści artystów, oprócz ukazania przyczyn emigracji, dotyczyły także doświadczanych przez nich rozmaitych represji. W PRL istotnym elementem systemu kontroli stała się polityka paszportowa $\mathbf{a}^{6}$. Uzyskanie takiego dokumentu było zazwyczaj trudne, wymagające wielu zabiegów i determinacji. Paszport po powrocie z wyjazdu należało oddać do urzędu i nie można było mieć pewności, że ponownie się go otrzyma. Istniał też specyficzny rodzaj paszportu, pozwalający

\footnotetext{
${ }^{6}$ Zagadnienie to zostało dokładnie opracowane przez Dariusza S t o ł ę (2010).
} 
jedynie na jednorazowy wyjazd lub też umożliwiający podróż tylko do wskazanych krajów. Opisy politycznego represjonowania, za jakie należy uznać odmowę wydania paszportu, pojawiały się w wielu narracjach.

I to jest ważny kontekst - Polska, w której wszystko było beznadziejne, w związku z tym studiowało się dla sztuki. Po dyplomie próbowałem pracować w Polsce. Nie było to łatwe, to były tak zwane ręczne robótki, wszystko przechodziło przez rodzaj cenzury artystycznej i normalnej politycznej, tak więc nie było łatwo zrobić plakat, nie było zamówień bezpośrednich, słowem: już od lat postanowiłem wyjechać i to był moment na wyjazd. Po dyplomie, po śmierci mojej matki zostałem sam w Polsce, mój brat był w Stanach, siostra w Paryżu. W związku z tym postanowiłem wyjechać, starałem się o paszport przez kilka lat i jako bratu dysydenta politycznego nie chciano mi go dać przez siedem lat i potem postanowiono mi dać paszport, na który mogłem tylko wyjechać; chcieli mnie po prostu wyrzucić z Polski, co mi było na rękę [...]. Wyjazd był makabryczny w tym sensie, że cała moja historia została rozdana, sprzedana, oprócz kilku zeszytów, kilku pamiątek po rodzicach. Wyjechałem w małym fiaciku, który kupiłem sobie na wyjazd, i tak wyjechałem do Paryża (wywiad 4, Paryż, malarz, grafik, plakacista).

Artysta wspomina, jak polityka paszportowa była wykorzystywana przez władzę w celu pozbywania się z kraju osób niepożądanych. Technika manipulacji i opresji polegała m.in. na tym, że najpierw przez pewien okres (nawet kilkuletni) odmawiano prawa do wyjazdu, aby w końcu zezwolić na jednorazowe przekroczenie granicy. W praktyce oznaczało to wydalenie z kraju. Państwo prowadziło specyficzną politykę emigracyjną, wykorzystując swoje totalitarne mechanizmy na wiele sposobów.

W latach 80. władze polskie, mając świadomość, że przychylność okazywana uchodźcom polskim przez Zachód potęguje zainteresowanie Polaków wyjazdami z kraju, w sposób milczący tolerowały ich „ucieczki” za granicę. Prowadząc politykę tej „milczącej zgody”, rząd polski miał bowiem własne cele (G r z e g o r z e w s k a-Mi s c h k a 2000: 110).

Chodziło o pozbycie się ludzi niewygodnych dla systemu - nie tylko opozycjonistów, lecz także ludzi łamiących prawo. Innym celem było rozładowanie ukrytego bezrobocia i kryzysu mieszkaniowego. W rezultacie osiągano podwójny efekt: pozbywano się osób krytycznych wobec komunistycznego systemu, a jednocześnie - poprzez eksportowanie elementu kryminogennego - psuto opinię o Polakach i skutecznie zmniejszano sympatię społeczeństw zachodnich względem emigrantów. Egzemplifikację opisanej polityki milczącej zgody oraz specyficznych technik obchodzenia restrykcyjnych przepisów paszportowych można odnaleźć w narracji artysty migrującego w okresie stanu wojennego:

[...] ludzie lądowali w więzieniach, ja też jakąś bibułę przenosiłem, a poza tym im zależało, bym wyjechał. Paszportu to nie ma szans, bym go dostał, ale przez paszport służbowy, to znaczy że będzie umowa między polską agencją artystyczną a teatrem i będę im płacił 5 procent, a ja dostanę paszport i to się będzie nazywało, że to jest oficjalny wyjazd. I wyjechałem, tyle że nie jak planowałem w styczniu, ale pod koniec września (wywiad 4, Londyn, aktor, grafik, scenograf, wykładowca). 
Obok opowieści osób pragnących wyjechać z kraju pojawiły się narracje, w których podkreślano decydujący wpływ nieoczekiwanego splotu okoliczności. Motyw „niechcianej” emigracji, wywołanej sytuacją polityczną w kraju, ujawnił się wielokrotnie. Emigracja taka posiada cechy przeżycia trajektoryjnego; jednostka, teoretycznie mając możliwość podejmowania decyzji, w praktyce postawiona jest w sytuacji odbieranej przez nią jako skrajnie represyjna i „bez wyjścia”. W kolejnym przypadku narrator zdecydował się na pozostanie poza Polską, nie godząc się na ustępstwa i negocjowanie z przedstawicielami władzy:

\begin{abstract}
Zacznijmy od tego, że nigdy nie miałem zamiaru wyjeżdżać z Polski, nigdy takiego planu nie miałem. Mój plan polegał na tym, żeby jeździć pomiędzy Polską a różnymi krajami na świecie, kontynuować tego rodzaju misję, nawiązywać kontakty artystyczne ważne dla mojej twórczości, poznać, co się dzieje, zobaczyć, co się dzieje, poznać świat. Ale okazało się to niemożliwe. Próbowałem otrzymać paszport wielokrotny, który by mi to umożliwił, ale mi go odmawiano. Próbowano terroryzować moich znajomych, moją matkę, było włamanie, wszystko zostało przewrócone do góry nogami, ale nic nie zostało ukradzione. Mama poszła na milicję, a milicja: $C z y$ coś zostało ukradzione? Nie. To nie nasz wydziat. Czyli przeczytano wszystkie listy, sfotografowano także je, tak to wyglądało. Chodziło o to, że ja nie wyjechałem z Polski, tylko Polska zaproponowała mój powrót na warunkach takich, których nie mogłem przyjąć. Dlatego te wszystkie terroryzowania i trzymania wszystkich ludzi w szachu, niedawania im paszportu w zamian za powrót, sugerowałoby, że stałbym się współpracownikiem bezpieki. A na układy z bezpieką nie można iść. Co to znaczy, my im damy, jak obywatel wróci, to znaczy, że stanie się agentem. Ja się na taki powrót nie mogłem zgodzić (wywiad 20, Nowy Jork, artysta multimedialny).
\end{abstract}

W zacytowanym fragmencie opowieści po raz kolejny opisany został mechanizm represjonowania jednostki poprzez ograniczanie swobody przemieszczania się. Narrator ujawnia też o wiele dalej posunięte interwencje państwowego aparatu kontroli, charakterystyczne dla lat 70. i 80. - inwigilację oraz zastraszanie. Biograficzny plan narratora zakładający poruszanie się pomiędzy Polską a innymi państwami musiał ulec modyfikacji. Swoje podróże artysta traktował w kategoriach misji i obowiązku. Ich celem miało być nawiązywanie kontaktów z innymi twórcami na świecie (także po to, by ożywiać programy wystawiennicze polskich galerii), umożliwienie kontaktów między środowiskami w kraju a artystami przebywającymi na emigracji oraz prowadzenie wykładów na temat Polski i polskiej sztuki. Plan ten udało się zrealizować dopiero po emigracji artysty.

\title{
4. Emigracje do Berlina Zachodniego: opowieści artystek
}

Polscy artyści emigrowali do wielu zachodnich państw, jednak w latach 80 . jednym z dominujących kierunków stała się Republika Federalna Niemiec, głównie zaś Berlin Zachodni. W narracjach berlińskich opisany został szereg okoliczności skłaniających twórców do emigracji oraz dotkliwy system doświadczanych przez nich represji. 
W końcu lat osiemdziesiątych wyjazdy osób należących do kręgu twórców polskiej kultury w Niemczech można usystematyzować według następujących motywacji: 1) polityczne - ucieczka od państwa totalitarnego; możliwość zrobienia w Niemczech kariery poza układami partyjnymi; 2) rodzinne - łączenie rodzin; 3) materialne - możliwość znalezienia pracy w Niemczech; 4) turystyczne - możliwość dalszej emigracji (K a l c z y ń s k a 2002: 399).

Obok czynników decydujących można wyznaczyć wiele innych powodów towarzyszących i wzmacniających decyzję o emigracji. Jak zawsze układ czynników push i pull okazał się zmienny i dynamiczny, uzależniony od warunków historycznych, osobistych doświadczeń i wielu innych okoliczności biograficznych. Emigracja Polaków do Berlina Zachodniego nasiliła się po wprowadzeniu stanu wojennego. Wielu artystów zaczęło wtedy podejmować próby tymczasowego lub trwałego opuszczenia kraju. Plany te nie zawsze oznaczały chęć udania się na trwałą emigrację. Często ich głównym celem było pragnienie uczestniczenia w wydarzeniach artystycznych poza krajem. Sami artyści, o czym opowiadali także twórcy z innych miast, otrzymywali zaproszenia od różnych europejskich i światowych instytucji zajmujących się kulturą. Z reguły jednak nie mogli z nich korzystać. Powodem tego była, opisana już wcześniej, restrykcyjna polityka państwa i ścisła kontrola w zakresie wydawania paszportów. Doświadczyła tego artystka performerka, której wielokrotnie odmawiano przyznania paszportu, uniemożliwiając jej tym samym uczestniczenia w prestiżowych imprezach artystycznych:

Otrzymywałam zaproszenia na wystawy i trzykrotną odmowę paszportu, bo ja tak naprawdę nigdy jeszcze nie byłam na Zachodzie, nigdy. Zawsze byłam zdania, że my tutaj robimy ośrodek sztuki, tak jak Galeria Adres, że do nas powinni przyjeżdżać, my nie potrzebujemy gdzieś emigrować, że u nas w Polsce dzieją się rzeczy ważne, że jesteśmy centrum, które te ważne sprawy realizuje, że oni muszą na nas spojrzeć, do nas przyjechać, od nas się uczyć. Sytuacja była taka, że podczas stanu wojennego dostałam wiele zaproszeń, planowano mnie zaprosić do Hiszpanii. Problem był taki ze mną, że ja nigdy nie dostawalam paszportu. Dostałam zaproszenie na taką imprezę towarzyszącą Biennale Weneckiemu, też dostałam odmowę. Te wszystkie odmowy spowodowały, że napisałam list do Ministerstwa Kultury i Ministerstwa Spraw Wewnętrznych, że jestem matką samotnie wychowującą dziecko, moim zawodem jest bycie artystką, żyję z własnej sztuki, i że teraz jest taka sytuacja, że jeśli nie dadzą mi państwo możliwości zarabiania, to muszą państwo wziąć odpowiedzialność za stan materialny mojej rodziny. I wreszcie po różnych perturbacjach i wizytach, oni dali mi paszport. To był listopad, 1982 rok. Kilku przyjaciół już w Berlinie Zachodnim na mnie czekało. Neue Berliner Kurseraum wysyłało mi takie sfingowane zaproszenia na dwa miesiące. Po tych wszystkich naciskach i pismach, po trzykrotnej odmowie paszportu, oni pozwolili mi wyjechać do Berlina Zachodniego. 25 listopada 1982 roku wsiadłam do pociągu. Wcześniej musiałam złożyć swoje prace do cenzury, i moje prace były ostemplowane można wywieźć (wywiad 3, Berlin, performerka).

Przytoczony fragment opowieści dowodzi, że w tym przypadku głównym czynnikiem push okazał się brak możliwości swobodnego przekraczania granic kraju i uczestniczenia w artystycznym życiu w skali europejskiej. Znaczenie miały też poważne problemy ekonomiczne samotnej matki. Wreszcie narratorka zwraca 
uwagę na szeroki zakres kontroli, jakiemu musiał się poddać artysta uzależniony od instytucjonalnej cenzury. Jednocześnie narratorka podkreśla, iż nie czuła się osobą represjonowaną w Polsce i nie chciała występować o azyl dla uchodźców politycznych, podobnie jak nie planowała trwałego pozostania w Berlinie:

Nie, bo ja nie wyjechałam po to, żeby uciec czy wziąć azyl, czy żeby w ogóle zrezygnować z kraju, ja cały czas jeszcze sądziłam, że wrócę do kraju. Poza tym artysta może pracować w kilku kulturach, on nie musi uciec (wywiad 3, Berlin, performerka).

W pewnym okresie trwania emigracji osoby niezdecydowane co do swoich biograficznych planów stają przed koniecznością odpowiedzi na fundamentalne pytanie dotyczące tego, czy pozostać w nowym kraju osiedlenia, czy też wracać do Polski. W przypadku artystki performerki ostateczna decyzja była następstwem rozmów z przyjaciółmi, ale przede wszystkim zdecydowanej postawy jej córki. W poniższym fragmencie wyraźnie uwidacznia się wpływ nowego milieu, w którym artystka znalazła się po opuszczeniu kraju.

Rozmawialiśmy o tym, ja mówiłam, że wrócę, a oni, że tam Jaruzelski, nawet mleka dla dziecka nie kupisz, stan wojenny, dziecko masz. Powinnaś tu zostać, popracować-mówili, nie masz po co tam wracać. A B. [córka artystki - przyp. T. F.] już od początku, jak weszła do sklepu, zobaczyła lalki, powiedziała: ja już nie wracam. Ja zawsze przeliczałam, a B.: ja już nie przeliczam, ja nie wracam. Ja miałam zapisany taki domek w Warszawie, tam była taka spółdzielnia Sztuka. Miały być budowane domki dla artystów. Mówiłam więc B.: może odłożymy na domek, a ona: ja już nie przeliczam (wywiad 3, Berlin, performerka).

Kolejna artystka także wyemigrowała w latach 80., choć nieco później niż osoba cytowana powyżej. Jej emigracje można zaklasyfikować w kategoriach uchodźstwa politycznego, chociaż - jak wyjaśnia poniższy fragment - nie bez znaczenia był osobisty czynnik o charakterze rodzinnym. W obu opowieściach istotnym wspólnym wątkiem uzasadniającym wyjazd z kraju była obawa o zdrowie i bezpieczeństwo dziecka:

Z jednej strony byłam, nazwijmy to, działaczem podziemia. Teraz po dwudziestu latach w Berlinie wydaje mi się to anachronizmem, bo moje życie tutaj nie opiera się na fakcie, że byłam uciekinierem politycznym. Niemniej jeśli mam się cofnąć o te dwadzieścia dwa lata, to muszę o tym powiedzieć. Byłam osobą czynnie działającą w opozycji w Gdańsku. Byłam żoną, matką kilkuletniego syna, która to nie miała szczęśliwego życia prywatnego. I do dzisiaj nie zmieniłam zdania, że jeśli komuś układa się życie osobiste, to jest w stanie znieść ciężar życia na zewnątrz. Jeżeli życie osobiste się nie układa, to ma się silne obciążenia, ale jakoś to wytrzymywałam. Wyjechałam w roku 1985, już miałam za sobą działalność w Solidarności [...] lącznie z krótkim aresztowaniem. Wtedy nie było już tak straszliwie, ale wcale jeszcze nie było nadziei, że zaraz potem będzie Okrągły Stół, rozmowy, obalenie muru i demokracja. Ja twierdzę, że nastąpiło zmęczenie materiału. Jakby coś trzasnęło. Ja po prostu stwierdzam, że już nie mogę, że nie mogę już patrzeć na faceta, jednego z trzech, który stoi przed moim domem, patrzy w okno i w ogóle się nie chowa, tu nie chodziło o to, żeby się chować, ale chodziło o to, żeby zastraszyć. On nie chciał się niczego dowiedzieć. Chodziło o to, żebym się bała. 
Ja już nie mogłam patrzeć na tego faceta. Pomyślałam, co będzie, jak oni mnie aresztują, a mój syn zostanie z matką w więzieniu? Ja już nie mogę patrzeć na chorobę mojego syna, która zaczęła się jak mnie aresztowano, co z tego, że aresztowano mnie na bardzo krótko, kiedy konsekwencje w życiu były straszne i ja już nie mogę znieść tego mężczyzny, z którym nie mogę się dogadać, a z którym w papierach mogę się dogadać świetnie (wywiad 2, Berlin, pisarka).

Decydującym powodem wyjazdu wydaje się zatem czynnik polityczny, choć narratorka kładzie nacisk na problemy w życiu osobistym. Kryzys małżeństwa mógł być równie silnym czynnikiem zmuszającym do ucieczki z kraju, jak systematyczne zastraszanie przez agentów Służby Bezpieczeństwa. W życiu narratorki skumulowały się silne bodźce skłaniające ją do emigracji, które w rezultacie doprowadziły do szybkiego podjęcia decyzji o wyjeździe z Polski:

To było czasowe, bardzo ostre zmęczenie materiału. Ale to spowodowało, że ja nie dojrzewałam do tego, to nie było planowane, przygotowywane, obstukane poprzez telefony. Ja po prostu stwierdziłam: nie, ja już mam dosyć. Jak będę mogła, to zabieram syna i wyjeżdżam. Nikomu nic nie mówię, jadę. I to zdanie wydaje się bardzo konkretne, ale to nie było konkretne. To było coś w rodzaju paniki takiego zwierzątka, które zostało zagonione i już nic nie wie, nic nie chce, nic nie może. Ja nie wiem, jaką bym podjęła decyzję, gdyby z uśmiechem nie wręczono mi paszportu dla mnie i dla syna, i nie powiedziano: do widzenia pani. Ja nie wiem, może zabrałabym syna, romantycznie wyjechałabym do jakiejś wioski mazowieckiej czy góralskiej. Ja musiałam coś w swoim życiu zrobić. To było całkiem niepraktyczne, bo jeżeli bym miała to obmyślać i przygotowywać, to musiałabym, po pierwsze: jechać do kraju anglojęzycznego, bo angielski znałam bardzo dobrze, a niemieckiego prawie w ogóle. [...] A ja wyjechałam do Niemiec, do Berlina, gdzie miałam dwie koleżanki, nieustawione (wywiad 2, Berlin, pisarka).

Pisarka - w przeciwieństwie do artystki performerki - od samego początku trwania swojej emigracji realizowała swój biograficzny plan trwałego osiedlenia się w Berlinie. W związku z tym wystąpiła o azyl dla uchodźców politycznych, którego uzyskanie wiązało się koniecznością przejścia długotrwałej i uciążliwej procedury. Doświadczenie opresji nie skończyło się zatem wraz z wydostaniem się z PRL. W nowym miejscu osiedlenia narratorka ponownie odczuwała zagrożenie i ponownie została poddana administracyjnym procedurom.

Jak przyjechałam, to pomyślałam, że nie chcę tam wracać, a jeśli nie chcę tam wracać, to muszę stawić temu czoła. I tak też zrobiłam, wystąpiłam o azyl. Przy czym nie wiem, jak tłumaczyć takie rzeczy, że zanim się wystąpiło w Berlinie o azyl polityczny, to trzeba było udać się do tzw. aliantów, czyli okupantów Berlina Zachodniego i udzielić im wywiadu. Dopiero po udzieleniu takich wywiadów można było się zgłosić do urzędu do spraw cudzoziemców w Berlinie Zachodnim i złożyć podanie o azyl. Było to o tyle skomplikowane, że okazało się, że albo działałam i miałam sporo do powiedzenia, bo znałam angielski, a ci wywiadowcy znali angielski, albo dlatego, że potrafiłam interesująco opowiadać, ja udzielałam wywiadów dwa tygodnie, jeździłam codziennie. Mało tego, ci Amerykanie, Francuzi za te wywiady płacili. Oni płacili jakąś sumę, powiedzmy było to 20 marek dziennie. Brałam te pieniądze, bo wydawało mi się to normalne, z czegoś muszę żyć, za te 20 marek mogłam kupić jedzenie dla siebie i dla syna. Natomiast jak przyszła Amerykanka z teczką, na której było napisane: confidency, tak powiedziała, że nie biorę żadnych pieniędzy, ja nie jestem żadnym konfidentem. 
Powiedziałam, że będę im udzielała wywiadów do tych tekstów, ale nie będę brała za to żadnych pieniędzy. Ona nie mogła tego zrozumieć. Ja próbowałam jej wytłumaczyć, że słowo konfident ma tak straszne znaczenie w Polsce, tak obciążone, że ja nie byłam w stanie zostać konfidentką. Było mi przykro, że wzięłam te pieniądze od Francuzów, ale nie wiedziałam, że jestem konfidentką. No więc przez dwa tygodnie opowiadałam im dziwne historie i odpowiadałam na ich dziwne pytania, najpierw myślałam, że robią to, żeby mnie sprawdzić. Po dwóch dniach zorientowałam się, że nie chcą mnie sprawdzić, ale rzeczywiście chcą informacji. Ich pytania dotyczyły struktury władzy, społeczeństwa, jak i samej struktury działań opozycyjnych. Mam nadzieję, że nigdy nie powiedziałam nic złego na nikogo (wywiad 2, Berlin, pisarka).

Przytoczony fragment opowieści ukazuje moralne dylematy, przed jakimi mógł stawać emigrant polityczny, doświadczając konieczności składania zeznań służbom wywiadowczym innych państw. Ponadto przejście przez forsowne przesłuchania $\mathrm{w}$ żaden sposób nie przyspieszyło procedury otrzymania azylu, która w rezultacie przedłużyła się do dwóch lat. Narratorka była przekonana, że otrzyma zezwolenie na stały pobyt w RFN, z czasem jednak pojawiły się rozmaite niedogodności związane z przejściowym statusem osoby oczekującej na azyl. Pierwsza obawa wynikała z potencjalnego niebezpieczeństwa otrzymania urzędowego nakazu osiedlenia się poza Berlinem Zachodnim, zaś druga niedogodność wiązała się z koniecznością zamieszkania w schronisku dla azylantów. Obie te groźby destabilizowały próby normalnego funkcjonowania podejmowane przez narratorkę:

Nie musiałam się niepokoić, czy dostanę ten azyl, ale zaczęłam się niepokoić o rzeczy formalne, biurokratyczne, a mianowicie z jednej strony ludzie przyjeżdżający do Berlina składający podanie o azyl byli najczęściej wysyłani gdzieś poza Berlin, wprawdzie nie rozdzielali rodzin, ale ja chciałam być w Berlinie, nie chciałam, żeby mnie wysłano do wioski, nawet najpiękniejszej gdzieś w Niemczech Zachodnich, gdyż ja jestem człowiekiem wybitnie miejskim. Ja lubię, żeby było dużo miasta w mieście. Zgłosiłam, że ja bardzo proszę, żeby mnie zostawiono w Berlinie, miałam wybitnie dużo szczęścia, nie musiałam nawet bardzo o to walczyć, po prostu mnie zostawiono (wywiad 2, Berlin, pisarka).

\section{Reakcje gospodarzy - krótkotrwala solidarność}

Innym interesującym (choć możliwe, że marginalnym) zagadaniem jest to, jak na początku lat 80. na emigrujących Polaków reagowali gospodarze. W kilku narracjach zebranych w Paryżu ujawniło się intensywne, choć dość krótkotrwałe zjawisko „polonofilii”. Doświadczył tego narrator, który w momencie ogłoszenia stanu wojennego znajdował się już w Paryżu, gdzie został zaproszony na trzy miesiące $\mathrm{w}$ celu prowadzenia wykładów. Wtedy też zetknął się on ze zjawiskiem, które w innych narracjach zostało przywołane jeszcze wielokrotnie, a które w tym przypadku łączy się z procesem ułatwionej i przyspieszonej legalizacji pobytu we Francji. Eksplozja solidarności i sympatii Francuzów w stosunku do Polaków po tym, jak ogłoszono stan wojenny, przejawiała się na wiele sposobów. 
No i 13 grudnia, ja dopiero pierwsze seminarium odbyłem, ogłoszono stan wojenny. I Francuzi zachowywali się wtedy niesłychanie życzliwie dla Polaków. Jak przyszedłem na to seminarium, to mi powiedzieli, że oczywiście przedłużają mi ten kontrakt, że przecież nie będę wracał w takiej sytuacji (wywiad 16, Paryż, naukowiec, felietonista).

Nie tylko administracja sprzyjała rozluźnieniu procedur legalizujących pobyt we Francji. Autor zacytowanej powyżej narracji zetknął się też z wyrazami sympatii ze strony osób prywatnych poruszonych sytuacją Polaków. W swojej opowieści zaznacza, że w pewnym stopniu sam był sprawcą owego poruszenia:

Zaproszono mnie do telewizji i zapytano, co się dzieje w Polsce. I odpowiedziałem, że można coś zrobić dla Polaków, którzy na święta wybierali się do Polski, a oni oczywiście wydali wszystkie pieniądze na prezenty, to trzeba im coś dać, przechować ich do czasu, kiedy będą mogli wrócić do Polski. I następnego dnia zgłosił się do mnie jakiś facet i powiedział, że słyszał mnie w TV i że chciałby mi zostawić dom pod Paryżem, żebym tam przygarnął Polaków. Że mnie poznał z TV i dzwonił tam, gdzie pracowałem. I w ten sposób znalazłem się pod Paryżem, w bardzo bogatej miejscowości niedaleko Wersalu. Dom był za darmo na czas nieokreślony, nasi sąsiedzi przyjeżdżali raz na miesiąc, ale nie po to, by nas kontrolować, tylko by nam przywieźć ostrygi. I ten dom zaczął się bardzo szybko zapełniać. Tam były trzy pokoje na górze, dwa na dole, ogromny salon, który był bawialnią, telewizornią. Pięć pokoi, w których mieszkało przynajmniej pięciu Polaków. Jeden pokój zająłem ja, jeden Agnieszka Holland, w jednym owa dziewczyna, do której przyjechał jej chłopak Jacek Gąsiorowski, taki reżyser filmowy. Nowy chłopak. W jednym pokoju Jacek Karczmarski i w jednym taki malarz - Marek Szczęsny. Jak już tam mieszkaliśmy, to przyjeżdżały tam tabuny Polaków (wywiad 16, Paryż, naukowiec, felietonista).

Potwierdza to kolejny respondent, podkreślając, że ten stan rzeczy realnie przekładał się na ówczesne możliwości emigrujących do Francji Polaków, zarówno w zakresie legalizowania pobytu, jak i podejmowania dobrej, prestiżowej pracy.

Stan wojenny wywołał taki jakiś okres olbrzymiej sympatii do Polski, może dlatego, że tam się kształtowała jakaś nowa jakość [...] był to okres sympatii, kiedy miałem te kłopoty administracyjne, to one znikały; Polakom udawały się rzeczy niespotykane ani wcześniej, ani później, na przykład otrzymanie stanowiska na wyższych uczelniach. Wtedy takie propozycje dostawało się prawie że z dnia na dzień. Wiele osób dostawało się do TV, do różnych takich miejsc (wywiad 3, Paryż, performer).

Podobnej sytuacji doświadczył kolejny artysta, który w tym okresie przebywał we Francji i starał się zalegalizować swój pobyt:

[...] to były te czasy, gdzie - można tak złośliwie powiedzieć - we Francji była moda na Polaków, [...] i było zawsze modne pokazać, że ma się młodego artystę Polaka podopiecznego, w tych dużych, ważnych kręgach było to zawsze dobrze widziane. Do 1986 moda była na Polaków (wywiad 11, Paryż, fotograf).

Wiele osób rozpoczynających swoją emigrację w połowie lat 80. zetknęło się we Francji z rozmaitymi przejawami życzliwości i zainteresowania polskimi sprawami. Wątek ten pojawił się w jeszcze jednej narracji artystki, która właśnie 
w tym okresie rozpoczynała swój pobyt w Paryżu. Tym razem jednak, jak podkreśla narratorka, był to już końcowy okres propolskich sympatii i zaczęły się rozmaite problemy administracyjne:

Gdy tylko przyjechałam, to był rok 1985, to była Solidarność, Wałęsa, słynny papież i taki entuzjazm. Ja przyjechałam na końcówkę entuzjazmu dla Solidarności (wywiad 14, Paryż, rzeźbiarka).

W dalszej części narracji artystka opisała swoje doświadczenia wówczas, gdy fala francuskiego entuzjazmu gwałtownie opadła. Wpłynęło to także na sytuację wielu Polaków, a w przypadku tej właśnie artystki niemalże zakończyło się deportacją. Biorąc pod uwagę kierowane do artystów wyrazy sympatii, warto byłoby zbadać to, czy doświadczali jej także przedstawiciele innych grup zawodowych i społecznych, czy też skupiała się ona głównie na elitach symbolicznych.

\section{Podsumowanie}

Stan wojenny w narracjach wielu artystów opuszczających Polskę w latach 80 . był czynnikiem decydującym lub też bardzo silnie wpływającym na podjęcie decyzji o emigracji. Posługując się teorią Everetta S. Lee - był to klasyczny, silny czynnik push. Wyjazdy te odbywały się w różnych warunkach, często przybierając trudny, nieraz dramatyczny charakter. Konsekwencją emigracji podejmowanych w tym okresie mogło być m.in.: długotrwałe rozstanie z bliskimi osobami, niemożność powrotu do kraju, zerwanie kontaktów z polskim środowiskiem artystycznym, utrata znaczącej części życiowego dorobku (także prac artystycznych). Podczas gdy dla niektórych twórców był to impuls do budowania kariery o światowym zasięgu, dla innych emigracja oznaczała początek życiowej trajektorii, pojawienie się poczucia marginalizacji, niespełnienia, wykluczenia. Wielu artystów nie było w stanie rozpocząc lub skutecznie kontynuować rozwoju swojej kariery poza Polską. Musimy pamiętać o ogromnym wysiłku, jaki wiąże się z rozpoczęciem życia na nowo w odmiennym środowisku kulturowym, o kosztach związanych z utratą społecznego zaplecza, o kłopotach wynikających z konieczności posługiwania się obcym językiem. „Emigracyjność oznacza inne formy istnienia, zerwanie ze »starym « i nowy »początek«, oznacza nierzadko niewiarygodny i kosztowny w sensie psychologicznym trud ukonstytuowania siebie jako niezależnej jednostki w świecie zupełnie obcym i innym" (D ą b row sk i 2001: 20).

W warunkach zjednoczonej Europy łatwo zapomnieć, jak kłopotliwym przedsięwzięciem było osiedlanie się $\mathrm{w}$ zachodnim państwie. Łączyło się to z szeregiem uciążliwych procedur, które były opisywane przez wielu artystów zarówno z Berlina, Londynu, Paryża, jak i Nowego Jorku. Emigranci doświadczali rozmaitych kłopotów praktycznie w każdej sferze swojego nowego życia. Niejednokrotnie fragmenty opowieści dotyczące tego okresu ukazywały trajek- 
torię cierpienia, momenty całkowitego wyalienowania, zagubienia, niepewności co do przyszłości, często także silnie odczuwanej tęsknoty (tzw. „choroba emigrancka"). Proces legalizacji pobytu jest nieuniknionym etapem życia migranta, wówczas gdy chce on od strony formalnej znormalizować swój pobyt w nowym kraju zamieszkania. Jest to moment silnego działania mechanizmów instytucjonalnych, podporządkowujących i dyscyplinujących procedur biurokratycznych, które w istotny sposób wpływają na życie migranta. W biografii emigranta można wskazać wiele momentów intensywnego doświadczania opresji, zarówno przed wyjazdem z kraju rodzinnego, jak i na etapie osiedlania się i legalizowania pobytu w nowym kraju. Są to w obu przypadkach represje innego rodzaju, o różnym natężeniu i, co najistotniejsze, odmienne w swoich konsekwencjach. Zawsze jednak silnie determinujące życie jednostki.

Można zastanawiać się, biorąc po uwagę kulturotwórczą funkcję artystów, na ile ich emigracje zubożyły rodzimą kulturę. Ich talenty i wiedza zostały w znacznej mierze spożytkowane poza Polską lub w wielu przypadkach nigdy się nie rozwinęły. Dla polskiej kultury bez wątpienia była to strata, jeśli bierzemy pod uwagę artystów, którzy nie chcieli trwale emigrować z Polski, którzy nie odnaleźli się poza krajem, pozostając $\mathrm{w}$ stanie liminalności lub doświadczając rozmaitych trajektorii cierpienia. $Z$ drugiej strony, dzięki wyjazdom wielu artystów mogło rozwinąć swobodną działalność artystyczną oraz zyskać, niemożliwą do osiągnięcia w Polsce stanu wojennego, stabilizację ekonomiczną i poczucie bezpieczeństwa. A zatem w kategoriach indywidualnych wyjazdy takie mogły okazać się, przy uwzględnieniu wszelkich psychologicznych i społecznych kosztów, niezwykle korzystne. Artyści emigrujący w latach 80. tożsamościowo pozostali Polakami, co jest typowe dla emigrantów pierwszopokoleniowych. Wielu z nich po pewnym okresie odnowiło kontakty z ojczystym krajem, czasami nawet decydując się na reemigrację.

Reasumując, emigracja artystów i jej skutki wymykają się próbom jednoznacznego sklasyfikowania. W przypadku emigracji związanej z wprowadzeniem stanu wojennego możemy mówić o jej przymusowym, trajektoryjnym charakterze. Takie wyjazdy zawsze łączą się z doświadczeniem traumy oraz koniecznością późniejszego biograficznego jej przepracowania. Powoduje to, że w każdym poszczególnym przypadku bilans zysków i strat był odmienny, zarówno w wymiarze indywidualnym, jak i w kontekście szeroko rozumianej polskiej kultury.

\section{Bibliografia}

C h o d u b s k i A. (2003), Emigracja jako zjawisko cywilizacyjne, [w:] W. J. B u r s z t a, J. S e r w a ń s k i (red.), Migracja, Europa, Polska, Zakład Badań Narodowościowych PAN, Poznań.

D ą brow sk i M. (2001), Swój/Obcy/Inny. Z problemów interferencji i komunikacji międzykulturowej, Świat Literacki, Warszawa.

F e r e n c T. (2012), Artysta jako obcy. Socjologiczne studium artystów polskich na emigracji, Wydawnictwo Uniwersytetu Łódzkiego, Wydawnictwo PWSFTviT, Łódź. 
F e r e n c T. (2014), Ambiwalencja kategorii ,sukcesu” na przyktadzie opowieści polskich artystów emigrantów, „Sztuka i Dokumentacja”, nr 11, s. 91-100.

G ł o w a c k i J. (2004), Z głowy, Świat Książki, Warszawa.

G o 1 k a M. (2008), Socjologia sztuki, Difin, Warszawa.

Grzegor zew s k a-M i s ch k a E. (2000), Wyznaczniki polityczne polskiej emigracji do Austrii w latach 1980-1992, [w:] J. E. Z a m oj s k i (red.), Migracje polityczne XX wieku. Migracje i społeczeństwo 4, Instytut Historii PAN, Mazowiecka Wyższa Szkoła Humanistyczno-Pedagogiczna w Łowiczu, Wydawnictwo Neriton, Warszawa.

K a c z m a r c z y k P. (2005), Migracje zarobkowe Polaków $w$ dobie przemian, Wydawnictwo Uniwersytetu Warszawskiego, Warszawa.

K a l c z y ń s k a M. (2002), ,Emigracyjni” twórcy polskiej książki i prasy zamieszkali w Niemczech po 1989 roku, [w:] B. K 1 i m a s z e w s k i (red.), Emigracja z Polski po 1989 roku, „Biblioteka Polonijna", t. 36, Grell, Kraków.

L e e S. E. (1966), A Theory of Migration, „Demography”, No. 3, s. 47-57.

O s ę k a A. (1975), Mitologie artysty, Państwowy Instytut Wydawniczy, Warszawa.

S toła D. (2010), Kraj bez wyjścia? Migracje z Polski 1949-1989, Instytut Pamięci Narodowej, Instytut Studiów Politycznych PAN, Warszawa.

Wa r c h o 1-S c h 1 o t t m a n M. (2002), Emigracja z Polski do Niemiec po roku 1989 - próba portretu zbiorowego, [w:] B. K 1 i m a s z e w s k i (red.), Emigracja z Polski po 1989 roku, „Biblioteka Polonijna", t. 36, Grell, Kraków, s. 362-385.

\title{
Tomasz Ferenc
}

\section{MARTIAL LAW IN THE BIOGRAPHICAL STORIES OF POLISH ARTISTS EMIGRANTS}

\begin{abstract}
The introduction of martial law in Poland in 1981 had serious political, social and economic consequences. It is a period in which significantly increased the migration potential among Poles. This was reflected also among artistic environment. The article shows the fate of artists who have decided to leave the country or remain permanently outside Poland. From biographical stories of artists living in Paris, Berlin, London and New York fragments of narrations relating to this period ware separated and analyzed, due to show various migration circumstances in the context of personal, environmental and historical factors. Although the fate of individual artists had each time an individual shape, it is possible to reconstruct the social mechanisms commonly shared by most of immigrants. An important element of the text is describing the system of repression used by the authorities, such as the so-called passport policy. The text next to the presentation of the fate of Polish émigré artists, deals with the problem of emigration in the category of cultural loss which is bear not only by the individuals but also by whole society.
\end{abstract}

Keywords: emigration, artists, martial law, repression, passport policy, assimilation. 